\title{
THE PRECAMBRIAN RAPAKIVI SUITE AND SURROUNDING GNEISSES OF THE KAP FARVEL AREA, SOUTH GREENLAND
}

D. Bridgwater, J. Sutton and J.S. Watterson

The main geological events recognised from the southern tip of Greenland are as follows:

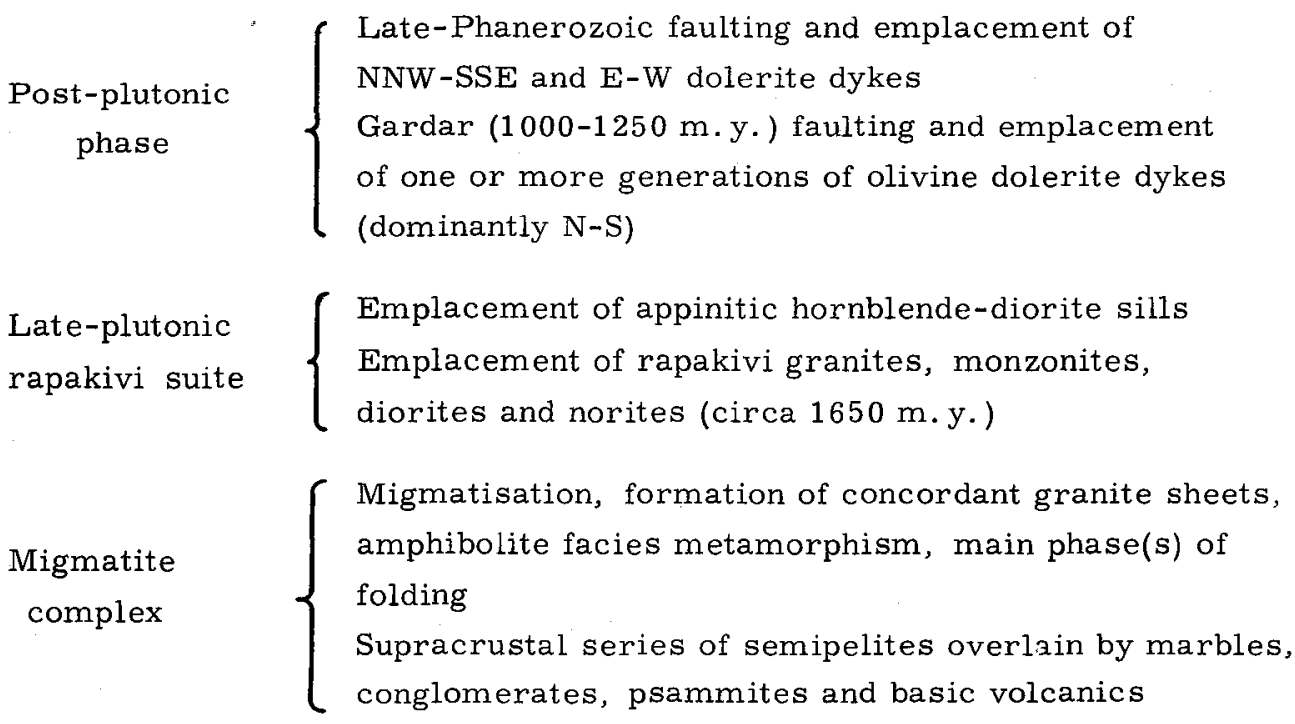

The rocks of the migmatite complex form generally flat-lying units with the most strongly migmatised rocks, semipelitic gneisses, underlying less altered psammites, conglomerates, marbles, and basic volcanics, which occur only in the northern part of the area.

A moderately sharp break between intensely migmatised and less migmatised rocks (a migmatite 'front') occurs towards the top of the sem1pelitic gneiss unit.

In the area studied the migmatite complex is of amphibolite facies but similar rocks to the north-west at the mouth of Tasermiut fjord, with granulite facies mineral assemblages may represent relics of an originally widespread pre-migmatisation granulite facies metamorphism.

The migmatitic supracrustal sequence contains concordant granite layers; one of these layers, at least $1 \mathrm{~km}$ thick and maintaining a more $\mathrm{cr}$ 
less constant stratigraphic level, can be traced almost continuously throughout the eastern half of the area. The concordant granite layers are potash-rich and contain garnet near to their contacts.

The migmatite complex is cut by numerous dykes and sills of basaltic composition, which although post-dating the main deformation of the migmatites are nevertheless locally deformed, and occasionally disrupted, by movements thought to be connected with emplacement of the main igneous suite. The basic dykes and sills have typical metamorphic textures in thin section and are hypersthene-bearing, and of a higher metamorphic grade than the surrounding gneisses. The dykes occasionally show intrusion features suggesting emplacement in plastic country rocks and no evidence has been found to show that these basic intrusions mark a cratogenic break in the metamorphic history of the area. The writers suggest that the present textures and mineral assemblages of the dykes are original features and are the products of crystallisation in a plutonic environment when the country rocks were at elevated temperatures and possibly undergoing regional metamorphism. It is suggested that the dykes may represent early members of the rapakivi suite.

The late-plutonic igneous suite of basic, intermediate and granitic rocks, which occupy nearly $50 \%$ of the total area (ca. $3000 \mathrm{~km}^{2}$ ) exposed in the Kap Farvel region, closely resemble the Finnish rapakivi granite suite. Isotopic age determinations suggest that the majority of these late plutonic granites were emplaced about $1650 \mathrm{~m} \cdot \mathrm{y}$. ago although local granitic activity continued to about $1500 \mathrm{~m} . \mathrm{y}$. (O. Larsen, this report). The intrusions are commonly sub-concordant to the general gneiss structure and locally form gently dipping sheets capping mountain tops. Where the intrusions are strongly discordant to the gently inclined regional structures, a steeply dipping structure has been imposed on the adjacent gneisses; at some localities at least the steep contact structures are the result of downwarping of adjacent gneisses rather than upwardly directed drag movement.

The early noritic or hornblende-dioritic members of the rapakivi suite are frequently preserved near to the contacts of the intrusions, either as a narrow border facies, as inclusions in the later monzonites and granites, or occasionally as basic masses several kilometres in extent. The early members of the suite frequently contain ovolds of potash feldspar with rims of plagioclase (rapakivi feldspar texture), which appear to have grown in situ. Although net-veining relationships between basic and granitic members occur, granitic material remained active after consolidation of the bas $c$ material. 
Within 1-2 km of the larger discordant igneous intrusions the country rocks show a change in both structure and metamorphism from the normal rocks of the migmatite complex. There is a change from amphibolite facies to brown-weathering granulite facies rocks and veins of garnet-hypersthene granite cut lower grade gneisses included in the high grade zone bordering the intrusions. In these border zones the regular structure of the well foliated and banded migmatites which is usual elsewhere, gives way to irregular plastic contortions, often without obvious continuity and with foliation absent or weakly developed. The development of this charnockitic border zone is thought to be closely related to the emplacement of the rocks of the rapakivi suite; however the relationship is complex since the youngest metamorphic effect of the granitic members of the suite commonly results in local downgrading of the surrounding gneisses.

It is tentatively suggested that the varying metamorphic effects of the rapakivi suite may be due to the movement of the water to and from the country rocks at different stages in the crystallisation history of the intrusions.

\section{PRELIMINARY INVESTIGATIONS IN SOUTH-EAST GREENLAND}

\section{Bridgwater}

As a first stage in planning a regional mapping programme on the south-east coast of Greenland from Scoresby Sund to Kap Farvel, the available material from previous expeditions has been examined and a provisional geological map is being compiled. A programme of isotopic age determination has been started in collaboration with F. J. Fitch (London University) and J.A. Miller (Cambridge University) in order to help localise areas in which to concentrate future detailed geological mapping. The Geological Survey of Greenland will be very pleased to receive information gathered on recent expeditions to this coast which may be of help in planning and which could prevent a senseless duplication of effort.

The Precambrian rocks from Kap Farvel to Kangerdlugssuaq consist 